(C) 2013

Панікар I. І., кандидат ветеринарних наук

Полтавська державна аграрна академія

Горальський Л. П., доктор ветеринарних наук

Житомирський національний агроекологічний університет

\title{
ОКРЕМІ ОСОБЛИВОСТІ ІМУНОМОРФОЛОГІЧНОГО СТАНОВЛЕННЯ ОРГАНІЗМУ ПОРОСЯТ ВІКОМ 9 ДІБ
}

\section{Рецензент - доктор ветеринарних наук П. І. Локес}

\begin{abstract}
Слабка активність клітин із маркерами CD79 (В-лімфочити) в лімфатичних утвореннях органів лімфопоезу і висока конщентрація циих клітин на поверхні слизової оболонки тонкого відділу кишечнику свідчить про незрілість власних гуморальних факторів імунітету поросят віком 9 діб і важливість материнських імунних тіл у житті новонароджених тварин. Активність лімфоичтів із поверхневими маркерами CD3 (тканинних лімфоцитів) більш виражена в лімфатичних вузлах і лімфоїдних утвореннях стінки кишечнику; особливістю даного проиесу с вогнищевий характер.
\end{abstract}

Ключові слова: активність, маркери, лімфоизити, поросята, імунітет

Постановка проблеми. Функцію першої лінії захисту організму до представників екзогенної мікрофлори виконують поверхневі клітинні структури та поєднані 3 ними гуморальні фактори, що, в свою чергу, асоційовані з покривним епітелієм шкіри та зовнішніх слизових оболонок, клітинних структур слизової оболонки кишечнику та інших порожнистих органів, а також із серозними покровами внутрішніх порожнин [1].

Аналіз основних досліджень і публікацій, у яких започатковано розв'язання проблеми. Шлунково-кишковий тракт відноситься до відкритих систем організму. Імунокомпетенція слизової оболонки забезпечується значною кількістю різних компонентів вродженого імунітету і представниками нормальної мікрофлори [4]. Кишечник знаходиться під суттєвим впливом екзогенних антигенів. До того ж контакт із ними за тривалого проходження їжі через травний тракт є досить тісним. Тому не дивно, що в ньому достатньо представлена лімфоїдна тканина, якій належить важлива роль у периферійній імунній системі [6].

В онтогенезі, як і в філогенезі, виникнення властивості до специфічної імунної відповіді клітинного та гуморального типів пов'язане 3 утворенням Т- і В-лімфоцитів. Т-лімфоцити, як регулююча система, впливають на формування субпопуляцій, цитокінів, експресію активацій- них молекул; вони здатні проявляти функціональну активність, спонтанну клітинну цитотоксичність як головний механізм системи імунобіологічного нагляду $[2,8]$.

Мета і завдання досліджень. Враховуючи, що становлення та функціонування імунної системи досліджене недостатньо і потребує до себе більш детальної уваги, метою нашої роботи було дослідження особливостей імуноморфологічного становлення організму поросят перших тижнів життя.

Для виконання поставленої мети було сформульовано завдання: провести гістологічні, морфометричні та імуногістохімічні дослідження органів імунопоезу поросят віком 9 діб.

Матеріали і методи досліджень. Гістологічні та морфометричні дослідження проводилися на базі науково-дослідної лабораторії кафедри патологічної анатомії та патофізіології ПДАА, імуногістохімічні - в клініко-діагностичній лабораторії діагностичного центру ТОВ «Аптека медичної академії» (м. Дніпропетровськ).

Досліджували поверхневі антигени лейкоцитів: CD3, CD79 у вторинних органах імунопоезу (лімфатичні вузли, селезінка, лімфоїдні утворення стінки кишечнику) поросят віком 9 діб.

Для дослідження відбиралися шматочки вищезазначених органів у забуферений нейтральний формалін. Світлову мікроскопію та фотографування одержаних гістологічних препаратів здійснювали за допомогою мікроскопа Olympus CX-41 та фотокамери Olympus C-5050.

Результати досліджень. У молодняка, на відміну від дорослих тварин, хімічний склад плазми крові відзначається віковими змінами. Результати проведених нами попередніх досліджень вказують на значні відхилення показників крові у тварин перших годин життя порівняно 3 тваринами віком 6, 9 та 14 діб.

Показники $\mathrm{A} / \Gamma$ коефіцієнту у тварин молочного періоду змінюються за рахунок збільшення фракції глобулінів, оскільки новонароджені поросята 3 молозивом матері починають отримува- 


\section{ВЕТЕРИНАРНА МЕДИЦИНА}

ти антитіла, що є складовою частиною фракції глобулінів. Так, рівень А/Г коефіцієнту 0,56 у тварин віком 9 діб свідчить про високий рівень фракції глобулінів у тварин даної групи [3].

Імунні фактори материнського молока та його окремі нутрієнти блокують заселення кишечнику умовно-патогенною флорою й сприяють росту біфідофлори. Остання стимулює синтез секреторного IgA та неспецифічних факторів імунного захисту (лізоциму, інтерферону, цитокінів, комплементу), що позитивно впливають на формування слизової оболонки травного каналу (природного бар'єра на шляху інфекційних та неінфекційних антигенів) [7, 9].

Проведеним дослідженням окремих показників гуморальної ланки імунної системи (CD3, CD79) нами встановлено, що у тварин віком 9 діб найбільшу кількість В-лімфоцитів (CD79) виявлено на поверхні слизової оболонки, а також у просвіті крипт слизової оболонки тонкого відділу кишечнику, що, на нашу думку, пов'язано 3 абсорбцією цих клітин саме з материнського молока. Крім того такі скупчення зареєстровано навколо кровоносних судин слизової оболонки. Цей процес пояснюється міграцією В-лімфоцитів у кров'яне русло.

У лімфоїдних вузликах стінки кишечнику, селезінки та лімфатичних вузлів ці клітини реєструються в незначній кількості (2-3 клітини) і розташовуються в центральній зоні вузлика, утворюючи світлі (герментативні) центри.

Відомо, що Т-лімфоцити (клітини з маркерами CD3) забезпечують клітинно-опосередковані форми захисту слизових оболонок.

Характер розташування Т-лімфоцитів також має свої особливості: у слизовій оболонці кількість Т-лімфоцитів значно менша, ніж В-лімфоцитів, що, з нашого погляду, пояснюється наявністю секреторного IgA та неспецифічних факторів імунного захисту, які попереджають адгезію мікроорганізмів та їх проникнення через слизову оболонку (рис. 1 А).

У лімфоїдній тканині травної трубки розташування клітин із маркерами CD3 займає 2/3 площі лімфатичного вузлика і має досить щільну концентрацію розташування вказаних вище клітин.

Відбувається нерівномірний розподіл клітин із маркерами CD3 по площі лімфатичного вузла. На великих ділянках кори характерною є дифузна інфільтрація лімфатичних вузликів клітинами даної групи з маркерами CD3 (рис. 2 A).
У лімфатичних вузликах таких ділянок добре виражений світлий (реактивний) центр.

В інших ділянках спостерігаються поодиноко розташовані по периферії лімфатичних вузликів клітини з маркерами CD3. В паракортикальній зоні клітини розташовані дифузно.

Водночас у селезінки характерним $є$ розріджене розташування Т-клітин із маркерами CD3 по всій площі органа в крайовій зоні лімфатичних вузликів (рис. 2 Б).

Таких клітин невелика кількість, - вони мають неправильну форму, нерівномірне забарвлення, зернистість цитоплазми. У періартеріальній зоні спостерігається значна концентрація таких клітин.

Навколо лімфатичних періартеріальних піхов спостерігаються видовжені утворення Т-клітин iз маркерами CD3 клітин; останні тісно прилягають до адвентицію судин.

На відміну від селезінки, в лімфатичних вузлах відбувається дифузне заселення лімфатичних вузликів Т-лімфоцитами, що є результатом міграції цих клітин із тимуса кровоносною системою до периферичних органів імунної системи. Кількість лімфоцитів у них варіює й представлено Т-клітинами відповідних субпопуляцій (Т-кілери і Т-хелпери у різному відсотковому відношенні).

\section{Висновки:}

1. Слабка активність клітин із маркерами CD79 (В-лімфоцитів) у лімфатичних утвореннях органів лімфопоезу і висока концентрація відповідно цих клітин на поверхні слизової оболонки тонкого відділу кишечнику свідчать про незрілість власних гуморальних факторів імунного захисту поросят віком 9 діб і важливість материнських імунних тіл у житті новонароджених тварин.

2. Активність лімфоцитів із поверхневими маркерами CD3 (тканинних лімфоцитів) більш виражена в лімфатичних вузлах i лімфоїдних утвореннях стінки кишечнику; особливістю даного процесу є вогнищевий характер.

3. Проведені дослідження свідчать, що на початку другого тижня життя організм поросят здатен протистояти патогенним впливам зовнішнього середовища за рахунок клітинної ланки власного імунітету, а гуморальний захист здійснюється завдяки імуноглобулінам, що надходять із молоком свиноматок. 


\section{ВЕТЕРИНАРНА МЕДИЦИНА}
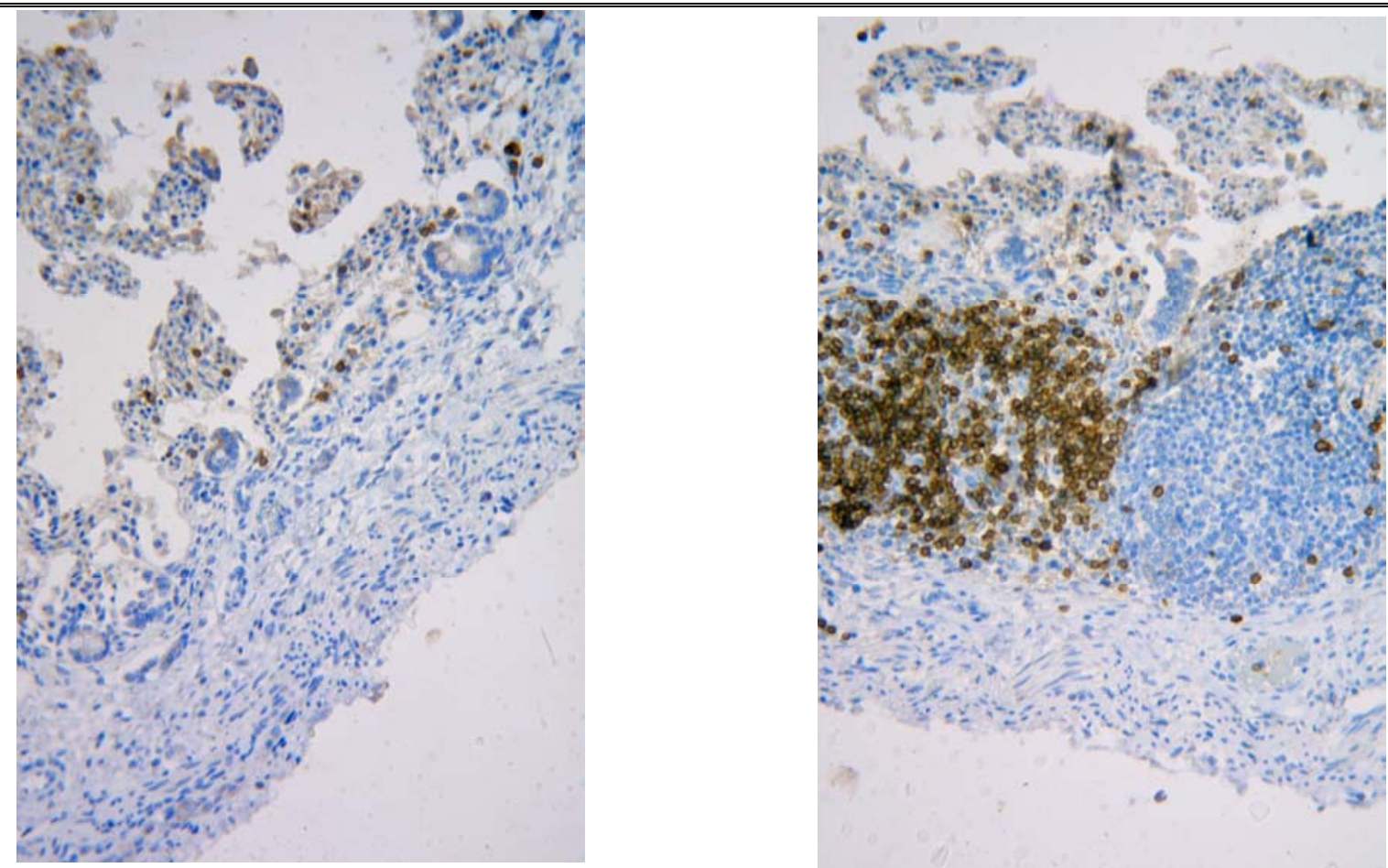

Рис. 1. Гістологічний препарат стінки тонкого відділу кишечнику з помірно виражсеною інфільтрацією слизової оболонки клітинами із маркерами СD3 (А); дифузне розташування клітин із маркерами СDЗ у лімфойдному вузлику (Б). Забарвлення гематоксиліном із додатковим дофарбовуванням гематоксиліном Майєра. Збільшення $\times 640(A$, Б).
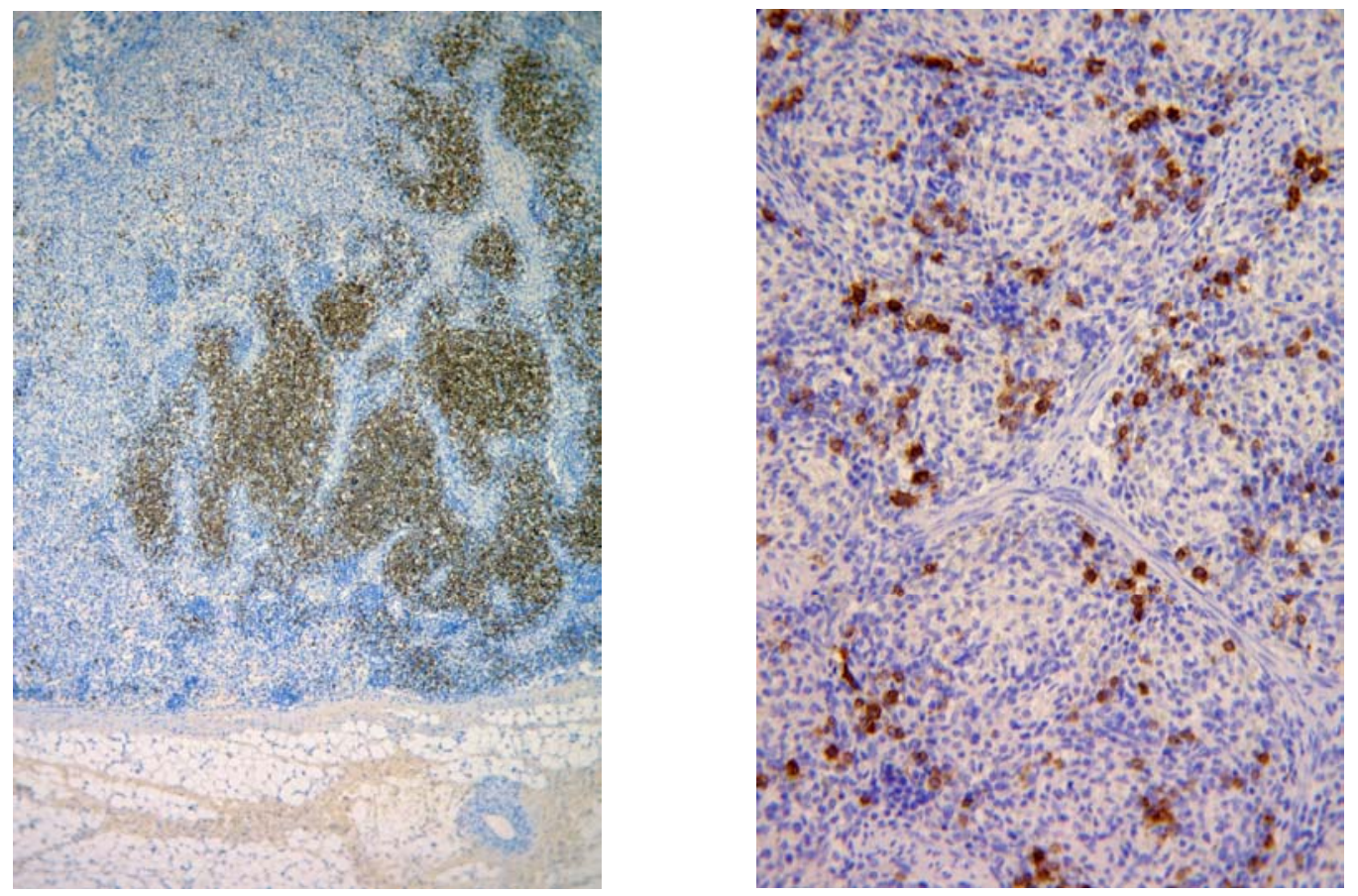

Рис. 2. Гістологічний препарат лімфатичного вузла з дифузним розташуванням клітин із маркерами CD3 (А); селезінки з периферійним поодиноким розташуванням клітинами із маркерами CD3 в білій пульпі (Б). Забарвлення гематоксиліном із додатковим дофарбовуванням гематоксиліном Майєра. Збільшення ×160 (А), ×640 (Б). 


\section{БІБЛІОГРАФІЯ}

1. Козлов В. К. Сепсис: имунопатогенез тяжелого сепсиса / В. К. Козлов // Клінічна імунологія. Алергологія. Інфектологія. - 2009. - №1-2. C. 17-24.

2. Ломасин М. С. Иммунобиологический надзор / М. С. Ломасин. - М. : Медицина, 1990. - 255 с.

3. Панікар I. I. Стан білкового обміну у поросят 2-тижневого віку / I. I. Панікар, К. А. Бугай, В. В. Гаркава // Наукові праці Полтавської державної аграрної академії. Серія: Ветеринарна медицина, 2013. - №6. - С. 57-62.

4. Сепиашвили Р. И, Пешкин В. И., Романюк Э. А. Иммунофизиология открытых систем организма // Аллергология и иммунология. - 2008. - Т. 9. №1. - C. 3-5.

5. Хаитов Р. М., Пинегин Б. В., Чередеев А. Н. Оценка иммунобиологической системы человека, современное состояние вопроса, сложности и достижения // Иммунология. - 1998. - №6. - С. 8-10.

6. Штылик A. B. Морфологические и функциональные нейроиммунные взаимодействия в Пейеровой бляшке тонкой кишки крыс. Автореф. дисс. ... канд. биол. наук. - СПб, 1999. - 19 с.

7. Abbott B. A. Infant feeding and maternal concerns about stool hardness / B. A. Abbott, A. Lucas // Child: care, health and development. 1997. - № 23. - P. 475-478.

8. Brown N. C., Rice-Ficht A. C., Estes D. M. Bovine type 1 and type 2 responses // Vet. Immunol. Immunopathol. - 1998. - V.63. - P. 45-55.

9. Walker W. A. Role of Nutrients and Bacterial Colonisation in the Development of Intestinal Host Defence // J Paediatr Gastroenterol Nutr. - 2000. 30. - P. 287. 